\title{
Relationship and Prediction of Body Weight from Morphometric Traits in Maefur Goat Population in Tigray, Northern Ethiopia
}

\section{Weldeyesus Gebreyowhens Berhe*}

The School of Graduate Studies, College of Dry Land Agriculture and Natural Resources, Ethiopia

\begin{abstract}
The study was conducted in Erob district eastern zone of Tigray, Northern Ethiopia to determine the relationship between live weight and linear measurements in Maefur goat population under traditional management system. Data on live body weight, linear body measurement and physical body character were collected from randomly selected 600 (297 male and 303 female goats) and categorized into age group of 04-12, 13-18, 19-24, and 24-35 months equivalent with to 0 PPI, 1 PPI, 2 PPI and $3 \geq \mathrm{PPI}$ with $82,87,134$ and 297 animals in each age groups, respectively. The data were analyzed using SPSS software 16.0 version. Descriptive statistics, correlation and regression analysis were used. Heart girth was highly correlated to body weight $(r=0.97, P<0.01)$ and used to predict live body weight with regression equations of $\mathrm{y} 1.04 \mathrm{x}-(43.3 \pm 0.83), \mathrm{R}^{2} 0.93$ for pooled sex and age. The multiple regression equation for prediction of the live body weight was $y=(0.74 \mathrm{HG}+0.16 \mathrm{BL}+0.18 \mathrm{HW})-42.8, R 2=0.95$ for pooled sex and age. It was concluded that, there is variability in body measurements across sex and age indicated that these measurements could be exploited in predicting live body weight. Heart girth was the major body trait used to predict live body weight.
\end{abstract}

Keywords: Maefur goat; Body measurement; Regression; Prediction equation

\section{Introduction}

Ethiopia has diversified agro ecology and various topography features, which served as a home for indigenous livestock species. Indigenous goats are among the economically important livestock species adapted in lowland, midland, and highland climatic condition. Nowadays, sustainable breed improvement in Ethiopia is an important concern in designing breeding strategy for indigenous goat population. The Institute of Biodiversity Conservation (IBC) documented the existing indigenous goat breeds found in Ethiopia. There are about 15 indigenous goat breeds so far identified in different part of Ethiopia. About four indigenous goat breed namely; Begait, Abergelle, Highland goat, and Maefur are found in the regional government of Tigray. Goat is a multi-functional animal and plays a significant role in the economy and nutrition of landless, small and marginal farmers in Ethiopia. Goat rearing is an enterprise which has been practiced by a large section of population in rural areas. The indigenous Maefur goat has a potential for meat production improvement. The male has deep heart girth and long body length with good potential in accumulation of meat around their neck and sternum. Implementation of breeding through selection using linear body measurement is important to increase meat yield from this breed through enhancing its live body weight. Proper measurement of live body weight, which is often hard in villages due to lack of weighing scale, is requisite for achieving this goal. The need for estimation of the live body weight from simple and easily measurable linear body traits (heart girth, body length and height at wither) is becoming important. Smallholder farmers practiced estimation of the body weights by looking on the animal body size (heart girth, body length and height at wither), leading to inaccuracies in decision making. Different models might be needed to predict body weight in different environmental conditions and breeds [1]. Studies regarding the linear body measurements of goat have been carried in other region of the world and their possible use for estimating the animals live weights [18]. Therefore, the present study was designed to observe body weight measurement relationship in Maefur goat population for selection and other purposes. Results obtained in present study would also be useful and helpful to farmers and animals scientists who are involved in small ruminants' research (Table 1).

\section{Materials and Methods}

\section{Study location}

The study was carried out in Erob district $\left(14^{\circ} 10^{\prime}-14^{\circ} 25^{\prime} \mathrm{N}\right.$ and $\left.39^{\circ} 40^{\prime}-39^{\circ} 50^{\prime} \mathrm{E}\right)$ found in Eastern zone of Tigray $47 \mathrm{~km}$ North east of Adigrat. Erob district was selected based on potential availability of Maefur goat breed as the information obtained (Figure 1). The maxima and minimum annual temperature of the study area ranges from 25 to $30^{\circ} \mathrm{C}$ and 12 to $16^{\circ} \mathrm{C}$, respectively. Altitude ranges between 1200 and $3000 \mathrm{~m}$ above sea level with mean annual rainfall ranges from 250 to $300 \mathrm{~mm}$ during the rainy months of June and August [9]. It has a notable topographic features include the Assimba and Ayga mountains. The study area has a diversified topographical features including peak mountainous (84\%), up and down hill $14 \%$ and plain area only $1 \%$. Erob has three agro-ecological classifications, highland 15\% (12750 ha), midland 75\% (63750 ha), and lowland 10\% (8500 ha) [9].

\section{Animals and management}

About 600 animals (297 male and 303 female goats) were used and divided in to four different age groups 04-12, 13-18, 19-24, and 2435 months equivalent with to 0 PPI, 1 PPI, 2 PPI and $3 \geq$ PPI with $82,87,134$ and 297 animals in each age group, respectively. They were managed under free grazing managment system of the smallholder farmer (Table 2).

\section{Data collection}

The variables measured included live weight recorded using Salter

*Corresponding author: Berhe WG, The School of Graduate Studies, College of Dry Land Agriculture and Natural Resources, Mekelle University, Ethiopia, Tel: +25190 233 5495; E-mail: welde26@yahoo.com

Received May 12, 2017; Accepted September 28, 2017; Published October 11 2017

Citation: Berhe WG (2017) Relationship and Prediction of Body Weight from Morphometric Traits in Maefur Goat Population in Tigray, Northern Ethiopia. J Biom Biostat 8: 370. doi: 10.4172/2155-6180.1000370

Copyright: ( 2017 Berhe WG. This is an open-access article distributed under the terms of the Creative Commons Attribution License, which permits unrestricted use, distribution, and reproduction in any medium, provided the original author and source are credited. 
Citation: Berhe WG (2017) Relationship and Prediction of Body Weight from Morphometric Traits in Maefur Goat Population in Tigray, Northern Ethiopia. J Biom Biostat 8: 370. doi: 10.4172/2155-6180.1000370

Page 2 of 6

\begin{tabular}{|c|c|c|c|c|c|c|c|c|c|c|c|c|}
\hline \multirow[t]{2}{*}{ Factors } & \multicolumn{12}{|c|}{ Linear body measurement } \\
\hline & HG & HW & HR & sw & BL & CD & EL & EW & HL & TL & HeW & HeL \\
\hline & \multicolumn{12}{|c|}{ Age group } \\
\hline $0 \mathrm{PPI}$ & $0.89^{* * *}$ & $0.67^{\star \star \star}$ & $0.55^{\star \star \star}$ & $0.25^{* *}$ & $0.55^{\star \star \star}$ & $0.31^{* * *}$ & $-0.24^{\star *}$ & $0.08^{*}$ & $0.37^{* * *}$ & $-0.15^{\star}$ & $0.03^{*}$ & $0.15^{*}$ \\
\hline $1 \mathrm{PPI}$ & $0.79^{* * *}$ & $0.37^{* * *}$ & $0.50^{* * *}$ & $-0.22^{* *}$ & $0.35^{\star \star *}$ & $-0.18^{*}$ & $0.13^{*}$ & -0.06 & $0.41^{* * *}$ & $0.36^{* * *}$ & $0.24^{* *}$ & $0.10^{*}$ \\
\hline $2 \mathrm{PPI}$ & $0.91^{* * *}$ & $0.78^{* * *}$ & $0.55^{* * *}$ & $0.37^{* * *}$ & $0.56^{\star * *}$ & $0.03^{*}$ & $-0.13^{*}$ & $-0.07^{*}$ & $0.42^{* * *}$ & $-0.01^{*}$ & $0.31^{* * *}$ & $0.04^{*}$ \\
\hline $3 \mathrm{PPI}$ & $0.95^{\star * *}$ & $0.88^{\star * \star}$ & $0.49^{* * *}$ & $0.39^{* \star *}$ & $0.87^{\star \star \star}$ & $0.59^{* \star *}$ & $-0.13^{*}$ & $0.03^{*}$ & $0.42^{* * *}$ & $0.09^{*}$ & $0.25^{\star \star \star}$ & $0.31^{* \star *}$ \\
\hline \multicolumn{13}{|c|}{ Sex } \\
\hline Male & $0.97^{* * *}$ & $0.93^{\star * *}$ & $0.68^{* * *}$ & $0.35^{\star * *}$ & $0.91^{* \star *}$ & $0.60^{* * *}$ & $-0.04^{*}$ & $0.03^{*}$ & $0.57^{* * *}$ & $0.15^{*}$ & $0.36^{* * *}$ & $0.41^{* * *}$ \\
\hline Female & $0.93^{* * *}$ & $0.77^{\star \star *}$ & $0.47^{\star * *}$ & $0.32^{* * *}$ & $0.80^{* * *}$ & $0.25^{\star * *}$ & $-0.02^{*}$ & 0.00 & $0.41^{* * *}$ & $0.32^{* * *}$ & $0.35^{\star * *}$ & $0.46^{* * *}$ \\
\hline Over all & $0.97^{* * *}$ & $0.90^{\star * *}$ & $00.65^{* * *}$ & $0.39^{\star \star *}$ & $0.88^{* * *}$ & $0.51^{* \star \star}$ & $-0.01^{*}$ & $0.04^{*}$ & $0.53^{* * *}$ & $0.19^{\star * *}$ & $0.39^{\star * *}$ & $0.45^{\star \star *}$ \\
\hline
\end{tabular}

***Significant at $(\mathrm{P}<0.01)$; ${ }^{* *}$ Significant at $(\mathrm{P}<0.05)$ and *not significant at $\mathrm{P}<0.05$.

Table 1: Correlations of body weight $(\mathrm{kg})$ to body measurements $(\mathrm{cm})$.

\section{Prediction of Live body weight by Heart girth in Maefur goat breed}

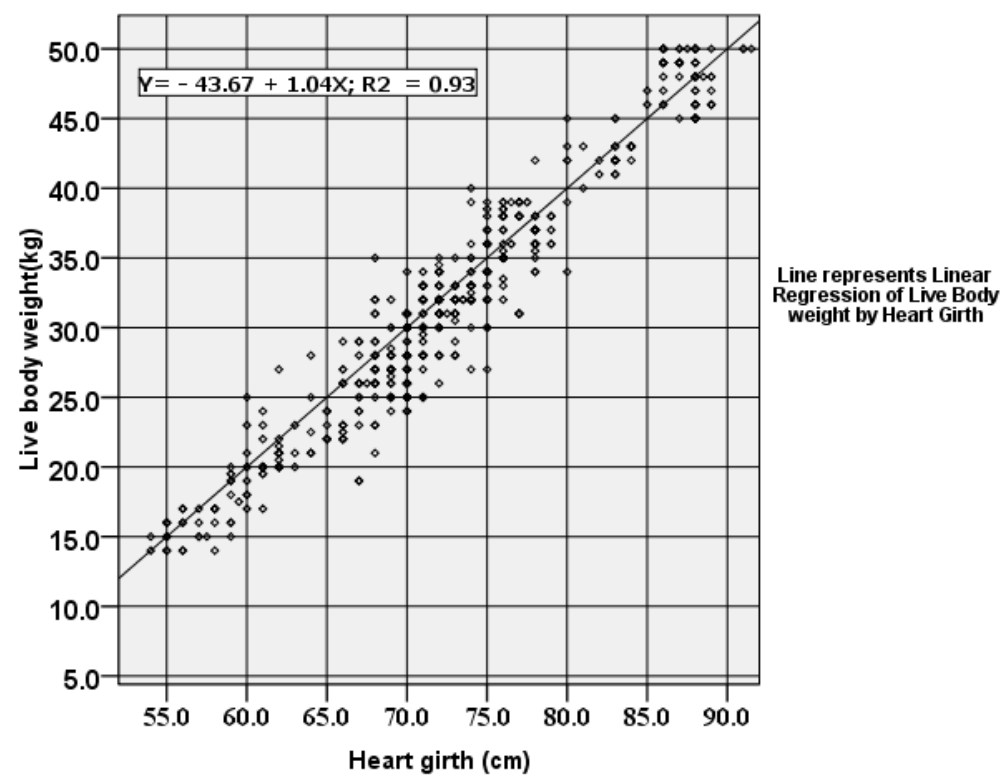

Figure 1: The linear relationship of live body weight to heart girth.

\begin{tabular}{|c|c|c|c|c|c|c|c|c|c|c|c|c|}
\hline Variables & HG & HW & RH & Sw & BL & CD & EL & EW & HL & TL & Hew & HeL \\
\hline $\mathrm{HG}(\mathrm{cm})$ & 1 & $0.89^{* *}$ & $0.67^{* *}$ & $0.41^{* *}$ & $0.86^{* *}$ & $0.51^{\star *}$ & $0-.02$ & 0.03 & $0.56^{\star *}$ & $0.18^{* *}$ & $0.39^{* \star}$ & $0.46^{* *}$ \\
\hline $\mathrm{HW}(\mathrm{cm})$ & & 1 & $0.68^{* *}$ & $0.45^{\star *}$ & $0.81^{* *}$ & $0.46^{\star *}$ & -0.03 & 0.04 & $0.45^{\star *}$ & $0.21^{* *}$ & $0.41^{* *}$ & $0.41^{* *}$ \\
\hline $\mathrm{RH}(\mathrm{cm})$ & & & 1 & $0.32^{* *}$ & $0.56^{* *}$ & $0.29^{\star *}$ & $0.11^{* *}$ & 0.07 & $0.35^{* *}$ & $0.17^{\star *}$ & $0.31^{\star *}$ & $0.37^{* *}$ \\
\hline Sw $(\mathrm{cm})$ & & & & 1 & $.32^{* *}$ & $0.3^{* *}$ & -0.02 & 0.04 & $0.25^{\star *}$ & $0.15^{\star *}$ & $0.24^{* *}$ & $0.28^{* *}$ \\
\hline $\mathrm{BL}(\mathrm{cm})$ & & & & & 1 & $0.54^{* *}$ & 0.00 & 0.04 & $0.50^{* *}$ & $0.15^{\star *}$ & $0.34^{* *}$ & $0.43^{* *}$ \\
\hline $\mathrm{CD}(\mathrm{cm})$ & & & & & & 1 & -0.05 & 0.06 & $0.36^{* *}$ & -0.01 & $0.14^{\star *}$ & $0.30^{* *}$ \\
\hline $\mathrm{EL}(\mathrm{cm})$ & & & & & & & 1 & $0.24^{* *}$ & 0.03 & $0.10^{*}$ & $0.08^{*}$ & $0.08^{*}$ \\
\hline $\mathrm{EW}(\mathrm{cm})$ & & & & & & & & 1 & -0.05 & 0.08 & $0.09^{*}$ & 0.05 \\
\hline $\mathrm{HL}(\mathrm{cm})$ & & & & & & & & & 1 & $0.20^{* *}$ & $0.27^{\star \star}$ & $0.38^{* *}$ \\
\hline $\mathrm{TL}(\mathrm{cm})$ & & & & & & & & & & 1 & $0.26^{\star *}$ & $0.14^{* *}$ \\
\hline Hew $(\mathrm{cm})$ & & & & & & & & & & & 1 & $0.26^{* *}$ \\
\hline $\mathrm{HeL}(\mathrm{cm})$ & & & & & & & & & & & & 1 \\
\hline
\end{tabular}

${ }^{*}$ Correlation is significant at the 0.05 level (2-tailed) and ${ }^{* *}$ Correlation is significant at the 0.01 level (2-tailed).

Table 2: Pearson correlation coefficients $(r$ ) between the body measurements.

scale with capacity of $50 \mathrm{~kg}$ (accuracy nearest $200 \mathrm{~g}$ ) and linear body measurements using meter tape $(1.5$ meter and accuracy $0.5 \mathrm{~cm}$ ) were recorded early in the morning, with the animals standing on a flat surface with head held up. About 12 linear body measurements namely, Heart girth (HG), Height at Withers (HW), HW ( Height at Wither), Height at Rump (HR), Shoulder Width (SW), Body length (BL), Chest Depth (CD), Ear length (EL), and Ear width (EW), Horn Length (HL), Tail Length (TL), Head Width (HeW) and Head Length 
Citation: Berhe WG (2017) Relationship and Prediction of Body Weight from Morphometric Traits in Maefur Goat Population in Tigray, Northern Ethiopia. J Biom Biostat 8: 370. doi: 10.4172/2155-6180.1000370

Page 3 of 6

(HeL) were recorded for all of the sampled animals. The anatomical reference points (ESGPIP, 2009) were as follows (Figure 2):

1. HG was measured by taking the circumference of the chest using a tailor's tape calibrated in $\mathrm{cm}$, taken as the circumference of the body immediately behind the shoulder blades in a vertical plane, perpendicular to the long axis of the body.

2. HW was measured as the distance from the ground to the withers.

3. BL was the distance from the head of humerus to the distal end of the pubic bone.

4. SW was measured as a distance between the shoulders.

5. CD was measured as the distance between the top behind the scapular and the flow of the sternum (taken to be the depth of brisket) immediately behind forelegs.

\section{Data analysis}

The data collected were subjected to standard statistical analysis. The means and standard error were determined for each trait. The coefficient of variation (CV) was calculated as the standard deviation divided by the mean multiply by 100 . The relationships amongst the measured characteristics were determined using correlation and linear regression analysis procedure of SAS (Table 3 ).

\section{Results and Discussions}

\section{Relationship of live body weight and linear body measurement}

Relationship between live body weights and linear body measurements was estimated by simple correlation and regression using Pearson correlation method. There was a significant correlation $(r=0.89 ; \mathrm{P}<0.01)$ between both heart girth and height at wither $(r=0.67$; $\mathrm{P}<0.01)$ with live body weight at early age (04-12 months). Similar research report suggests that either of this variable or their combination (heart girth and height at wither) would provide a good estimate for predicting live body weight at an early age [1]. Height at rump $(\mathrm{r}=0.55$ $\mathrm{P}<0.01)$ and body length $(\mathrm{r}=0.55 ; \mathrm{P}<0.01)$ high and positively correlated with live body weight at $04-12$ month. Similar finding is report by Fajemilehin and Salako [10] and is found to be higher than the findings of Khan et al. [1] who observed positive correlation of body weight to

Prediction of live body wieght by Height at wither for Maefur goat breed

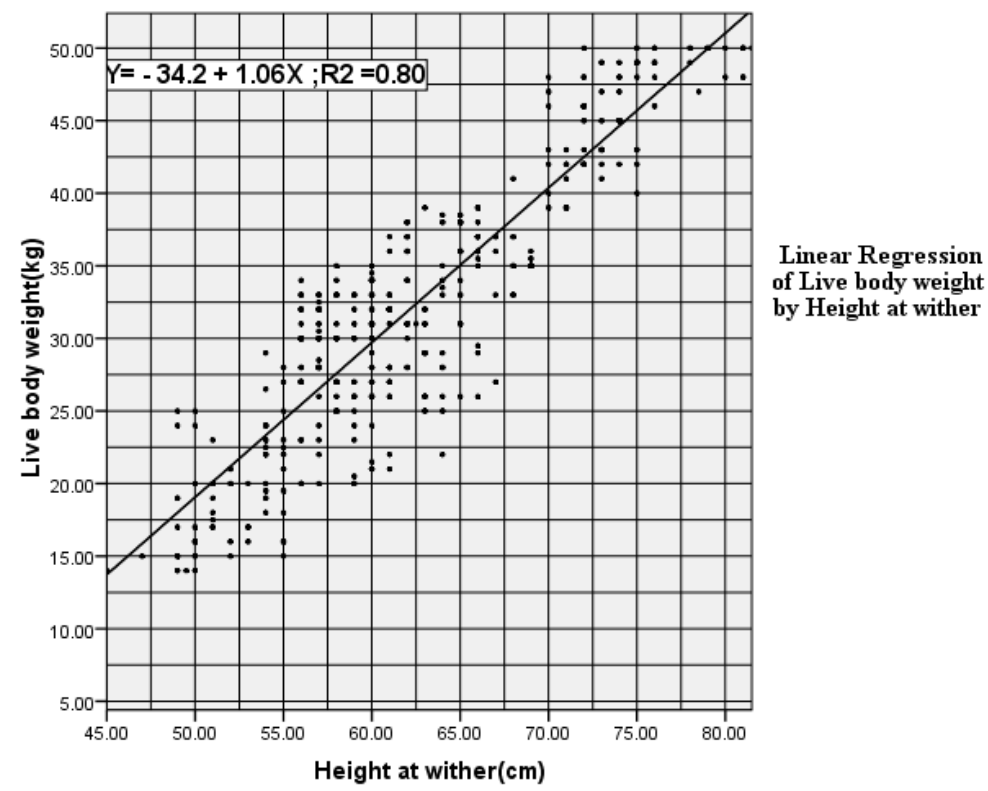

Figure 2: The linear relationship of live body weight to height at wither.

\begin{tabular}{|c|c|c|c|c|c|}
\hline Dependent & Independents & Regression equation & $T$ & Significance & Adj $R^{2}$ \\
\hline Live body weight & Hearth girth & $Y=-(43.7 \pm 0.83)+1.04 X$ & 91.4 & $P<0.000$ & 0.93 \\
\hline Live body weight & Height at wither & $Y=-(34.2 \pm 1.3)+1.06 X$ & 49.5 & $P<0.000$ & 0.80 \\
\hline Live body weight & Height at rump & $Y=-(29.4 \pm 2.95)+0.99 X$ & 20.8 & $P=0.16$ & 0.42 \\
\hline Live body weight & Shoulder width & $Y=(14.0 \pm 1.73)+1.66 X$ & 10.5 & $P=0.14$ & 0.15 \\
\hline Live body weight & Body length & $Y=-(20.2 \pm 1.13)+0.84 X$ & 46.6 & $P<0.000$ & 0.78 \\
\hline Live body weight & Chest depth & $Y=(20.1 \pm 0.86)+1.47 X$ & 14.6 & $P=0.607$ & 0.26 \\
\hline Live body weight & Ear length & $Y=(32.4 \pm 1.8)-0.05 X$ & -0.3 & $P=0.642$ & -0.001 \\
\hline Live body weight & Ear width & $Y=(30.1 \pm 1.8)+0.33 X$ & 0.9 & $P=0.427$ & 0.000 \\
\hline Live body weight & Horn length & $Y=(18.0 \pm 0.93)+0.87 X$ & 15.6 & $P=0.056$ & 0.29 \\
\hline Live body weight & Tail length & $Y=(21.1 \pm 2.27)+0.79 X$ & 4.7 & $P=0.251$ & 0.03 \\
\hline Live body weight & Head width & $Y=(22.8 \pm 0.92)+0.74 X$ & 10.9 & $P=0.951$ & 0.15 \\
\hline Live body weight & Head length & $Y=(10.9 \pm 1.74)+1.1 X$ & 12.2 & $P=0.478$ & 0.20 \\
\hline
\end{tabular}

Table 3: Stepwise simple linear regression equation to predict body weight. 
heart girth (0.64) and body length (0.49) and height at wither (0.75) but lower than for height at wither (0.75) at 4-12 months of age. In the second age group (13-18 months) the correlation coefficient declined to $\mathrm{r}=0.79 ; \mathrm{P}<0.01,0.37 ; \mathrm{P}<0.01,0.50 ; \mathrm{P}<0.01$ and $0.35 ; \mathrm{P}<0.01$ for heart girth, height at wither, height at rump and body length, respectively (Table 4). The reason might be the poor management, which lead to stunted growth and development with less flesh accumulation in relation to the adult age. In the adult age group (25-35 months) the correlation coefficient of these body measurement inclined to $(\mathrm{r}=0.95$; $\mathrm{P}<0.01,0.88 ; \mathrm{P}<0.01,0.49 ; \mathrm{P}<0.01$ and $0.87 ; \mathrm{P}<0.01$ ) for heart girth, height at wither, height at rump and body length, respectively. This result is disagreed to the previous findings reported by Alemayehu et al. [8] suggested that the high and positive correlation of body length $(\mathrm{r}=0.82)$ and height at wither $(\mathrm{r}=0.75)$ and live body weight at early age (04-12 month) indicates that better predication of live body weight at early age than at maturity.

\section{Application of LBM for estimation of live body weight}

Estimating the live body weight of goat is important for good management and husbandry, including appropriate medication, adjusting feed supply, monitoring growth and for selection of breeding males and females $[1,3,4]$. Body conformation measurements are important for introducing community based indigenous goat breed improvement through selective breeding system. However, most of the applications concerned with breed characterization rather than for providing framers with practical knowledge. Therefore, live body weight can be estimated without using scale in which live body weight is regressed on selected body measurements. Heart girth, body length and height at wither are the most important linear body traits for estimation of live body. Heart girth explains about 80.4 to $93.6 \%$ total variation in live body weight in Indian goat breed of Kanni Adu kids under farmer's management system. Live body weight is significantly correlated to heart girth $(r=0.899)$ and to body length $(r=0.729)$ for Gumuz, Begia-Medir and Agew goat ecotypes of the Amhara region of Ethiopia [11]. More recent finding for Abergelle goat breed emphasized that body weight has relatively high relationship with heart girth (0.73-0.89) as compared with the other body measurements, body length (0.46-0.82) and height at wither (0.53-0.83) [8]. Body weight and linear measurements are important body traits to select indigenous goat for meat production improvement by community based breed improvement through selection.

Heart girth $(\mathrm{r}=0.97 ; \mathrm{P}<0.01)$, height at wither $(\mathrm{r}=0.93 ; \mathrm{P}<0.01)$, height at rump $(r=0.68 ; \mathrm{P}<0.01)$ and body length $(\mathrm{r}=0.91$ : $\mathrm{P}<0.01)$ high and positively correlated to live body weight for male. They have high and positive correlation with live body weight with $(\mathrm{r}=0.93 ; \mathrm{P}<0.01$, $\mathrm{r}=0.90 ; \mathrm{P}<0.01, \mathrm{r}=0.65 ; \mathrm{P}<0.01$ and $\mathrm{r}=0.88 ; \mathrm{P}<0.01$ ), respectively for female. This finding is in line to reports and different breed reported by Khan et al. [1] and. Therefore, these body measurements are important as selection criteria for community based breed improvement for age and sex.

The correlation coefficient between live body weight and these measurements were $\mathrm{r}=0.97 ; \mathrm{P}<0.01$, and $\mathrm{r}=0.65 ; \mathrm{P}<0.01$ and 0.88 ; $\mathrm{P}<0.01$, respectively. This result is in collaborative to many findings reported by Khan et al. [1]. Heart girth was high and positively correlated to height at wither, body length and height at rump at $(\mathrm{r}=0.888 ; \mathrm{P}<0.01, \mathrm{r}=0.865 ; \mathrm{P}<0.01$ and $\mathrm{r}=0.671 ; \mathrm{P}<0.01)$, respectively. Most body measurement pairs were significantly $(\mathrm{P}<0.05)$ and positively correlated but ear length has negative correlation with heart girth, height at wither, shoulder width and chest girth. Therefore, the high correlation coefficient $(\mathrm{r}=0.97 ; \mathrm{P}<0.01)$ observed between body weight and heart girth for all dentition groups suggest that girth alone or in combination with other body measurements could provide a good estimate for predicting live weight of maefur goat breed. Heart girth, body length and height at wither had high correlation with the body weight. They have the potential advantage for implementing selective breeding programmes of the indigenous goat Maefur goat. Many earlier findings suggested that the importance of these major linear body measurement to estimate live body weight of goat under traditional managements system. These findings justified that these major body traits are important for implementing breeding through selection to improve meat production of the indigenous goat breeds. The major linear body measurement are important to indicate the stage growth and of development.

\section{Multiple stepwise regression analysis for body measurements}

When live body weight was regressed to linear body measurements, heart girth first entered. About $93.3 \%\left(\mathrm{R}^{2}\right)$ of the variation of pooled live body weight was explained by heart girth. Body length was the second entered body measurement in which the adjusted $\mathrm{R}^{2}(78 \%)$ contributed in explain the variation of the live body weight for overall male and female regression analysis. The third entered linear body measurement was height at wither in which the adjusted $\mathrm{R}^{2}$ explained about $80 \%$ the variation in live body weight. Heart girth was the most important body measurement to explain the variation of live body weight with the adjusted $\mathrm{R}^{2}$ values $95 \%$ and $80 \%$ in male and female, respectively [12-15]. About $5 \%$ and $20 \%$ of the unexplained variation in live body of male and female, respectively might happen because of the variation in feed and water availability not consider in this result. For pooled analysis without considering sex and age of Maefur indigenous goat breed, 12 linear body measurements were fitted to a model and through stepwise elimination procedure, three of the body measurements (heart girth, body length, and height at wither) were best fit for the model (Figure 3). In this study, three fitted equations were good at estimating live body weight from body measurements $\mathrm{R}^{2}$ of 0.78 to 0.93 . Heart girth alone estimated live body weight $\left(\mathrm{R}^{2}\right.$ of 0.93$)$. This result is in collaboration to the previous findings reported. Live body weight was better estimated using heart girth for age group 04-12 months for male $(\mathrm{N}=46)$ and female $(\mathrm{N}=36)$ as $-25.2+0.74$ Heart girth $\left(\mathrm{R}^{2}=0.69\right)$ and $-24.6+0.72$ Heart girth $\left(R^{2}=0.88\right)$, respectively. For the second group, live body weight was estimated for male $(\mathrm{N}=47)$ and female $(\mathrm{N}=40)$ as $-30.0+0.84$ Heart girth $\left(\mathrm{R}^{2}=0.74\right)$ and $-23.3+0.72$ Heart girth $\left(\mathrm{R}^{2}=0.43\right)$, respectively. For the third age group, live body weight was estimate for male $(\mathrm{N}=57)$ and female $(\mathrm{N}=77)$ as $-27.29+0.80$ Heart girth $\left(\mathrm{R}^{2}=0.74\right)$ and $-36.7+0.90$ Heart girth $\left(\mathrm{R}^{2}=0.84\right)$, respectively. $(0.90)$ was increased for the adult male (25-35 months and above). Height at wither $\left(\mathrm{R}^{2}=0.83\right)$ and body length $\left(\mathrm{R}^{2}=0.78\right)$ were used to estimate live body weight for the adult male with the reasonable accuracy whereas for the adult female still heart girth appropriate to estimate live body weight $[16,17]$.

Hence, it is better to predicted live body for the adult male and female Maefur indigenous goat using heart girth as $-38.7+1.0$ Heart girth $\left(\mathrm{R}^{2}=0.90\right)$ and $-44.4+1.1$ Heart girth $\left(\mathrm{R}^{2}=0.67\right)$, respectively. Therefore, heart girth is the best body trait used to predicted live body weight with reasonable accuracy. It indicates the simple linear regression equation using heart girth; body length and height at wither for pooled sex and age in separate. Live body weight was best predicted using heart girth for the age groups 04-12, 13-18, 19-24 and 25-35 months and above as $-25.5+0.7 \mathrm{HG}\left(\mathrm{R}^{2}=0.81\right),-30.5+0.8 \mathrm{HG}\left(\mathrm{R}^{2}=0.62\right)$ $-33.6+0.9 \mathrm{HG}\left(\mathrm{R}^{2}=0.83\right)$ and $-43.3+1.0 \mathrm{HG}\left(\mathrm{R}^{2}=0.90\right)$, respectively The accuracy of predication for live body weight enhanced for pool 
Citation: Berhe WG (2017) Relationship and Prediction of Body Weight from Morphometric Traits in Maefur Goat Population in Tigray, Northern Ethiopia. J Biom Biostat 8: 370. doi: 10.4172/2155-6180.1000370

Prediction of live body weight $(\mathrm{kg})$ by body length $(\mathrm{cm})$ in Maefur goat breed

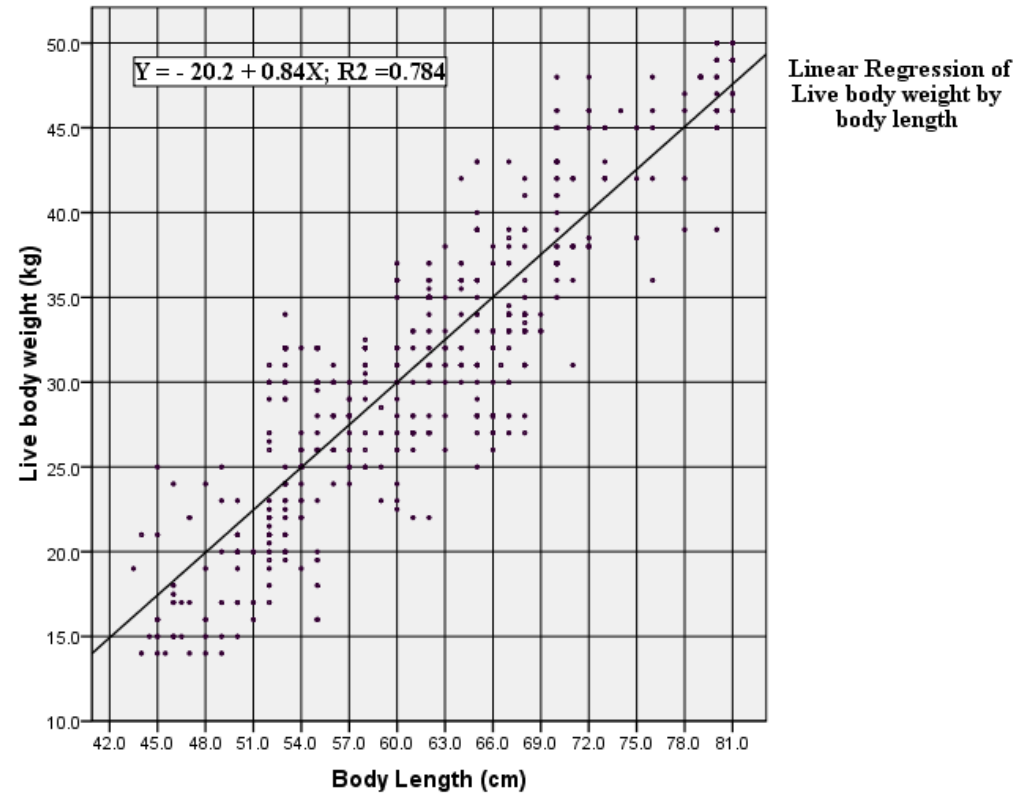

Figure 3: The linear relationship of live body weight to body length.

\begin{tabular}{|c|c|c|c|c|}
\hline Age & $\mathbf{N}$ & Model & $\mathbf{R}^{2}$ & P-value \\
\hline \multirow[t]{3}{*}{$04-12$ months $=1$} & \multirow[t]{3}{*}{82} & $-25.5+0.7$ Heart girth & 0.81 & $<0.0001$ \\
\hline & & $-15.3+0.6 \mathrm{Height}$ at wither & 0.44 & $<0.0001$ \\
\hline & & $-8.0+0.5$ Body Length & 0.29 & $<0.0001$ \\
\hline \multirow[t]{3}{*}{$13-18$ months $=2$} & \multirow[t]{3}{*}{87} & $-30.5+0.8$ Heart girth & 0.62 & $<0.0001$ \\
\hline & & $6.1+0.4$ Height at wither & 0.13 & 0.0004 \\
\hline & & 11.3+0.3 Body Length & 0.11 & $<0.0010$ \\
\hline \multirow[t]{3}{*}{$19-24$ months $=3$} & \multirow[t]{3}{*}{134} & $-33.6+0.9$ Heart girth & 0.83 & $<0.0001$ \\
\hline & & $-27.3+1.1$ Height at wither & 0.60 & $<0.0001$ \\
\hline & & $6.2+0.4$ Body Length & 0.31 & $<0.0001$ \\
\hline \multirow[t]{3}{*}{$25-35$ months and above $=4$} & \multirow[t]{3}{*}{297} & $-43.3+1.0$ Heart girth & 0.90 & $<0.0001$ \\
\hline & & $-24.6+0.9$ Height at wither & 0.77 & $<0.0001$ \\
\hline & & $-22.0+0.9$ Body Length & 0.76 & $<0.0001$ \\
\hline \multirow[t]{3}{*}{ M } & \multirow[t]{3}{*}{297} & $-43.7+1.0$ Heart girth & 0.95 & $<0.0001$ \\
\hline & & $-40.4+1.2$ Height at wither & 0.87 & $<0.0001$ \\
\hline & & $-20.2+0.8$ Body Length & 0.83 & $<0.0001$ \\
\hline \multirow[t]{3}{*}{$\mathrm{F}$} & \multirow[t]{3}{*}{303} & $-41.5+1.0$ Heart girth & 0.86 & $<0.0001$ \\
\hline & & $-23.0+0.9$ Height at wither & 0.58 & $<0.0001$ \\
\hline & & $-13.7+0.7$ Body Length & 0.64 & $<0.0001$ \\
\hline
\end{tabular}

Table 4: Predication equation of LBW for pooled sex and age group.

age using heart girth and was estimated at $-43.7+1.0 \mathrm{HG}\left(\mathrm{R}^{2}=0.95\right)$ and $-41.5+1.0$ Heart girth $\left(\mathrm{R}^{2}=0.86\right)$ for male and female, respectively. Therefore, study demonstrated that with increased age the accuracy of predication for live body weight using heart girth enhanced. It shows that live body weight can be predicated for pooled sex and age with enhanced accuracy of estimation using one or more variables. The coefficient of determination $\left(\mathrm{R}^{2}\right)$ is increasing as the number of variable in the equation increases. The increased $\mathrm{R}^{2}(0.93-0.95)$ indicates that how well fitted the multiple regression equation for predication of live body weight. Because of the high correlation between live body weight to heart girth in both sexes and all age groups, the simple linear equation without consideration sex and age group develop into:

$\mathrm{LBW}=-43.67+1.04 \mathrm{HG}\left(\mathrm{R}^{2}=0.93 ; \mathrm{N}=600\right.$ using heart girth only,
$\mathrm{LBW}=-40.83+0.85 \mathrm{HG}+0.19 \mathrm{BL}\left(\mathrm{R}^{2}=0.94\right)$ using heart girth and body length.

$\mathrm{LBW}=-42.77+0.74 \mathrm{HG}+0.16 \mathrm{BL}+0.17 \mathrm{HW}$ (adj $\left.\mathrm{R}^{2}=0.95\right)$ using heart girth, body length and height at wither. Based on this evidence live body weight can be predicted using heart girth, body length and height at wither with more accurate estimation but there are problems in handling of the animals under study especially under the pastoral and agro pastoral production system $[18,19]$. Among the previous studies, the more related findings to the result of the current study are the findings. Moreover, the accuracy of the equations was estimated using residuals (absolute value of the difference between predicted weight by using the developed equations and actual weight measured with the scale. In this regard, the standardized residual was between 
-3.7 and $3.7 \mathrm{~kg}$ whereas the standardized value was between -2.2 and 2.4 $\mathrm{kg}$. The analysis of residual statistics implies that the actual measured live body weight was in between the predicted value of live body weight $(\min =13.2 \mathrm{~kg}$; $\max =51.8 \mathrm{~kg}$; mean $31.8 \pm 8.44(\mathrm{SD})$. All regressions were done at $95 \%$ confidence interval, the error in predicting the body weight from the heart girth, body length and height at wither measurement would not exceed $2.4 \mathrm{~kg}$.

\section{Conclusion}

The study investigated the correlation of live body weight to linear body measurements in same breed of goats at different age with 600 maximum numbers of observations. To maintain good animal husbandry, the measurement of live body weight is essential for breeding, nutrition, and health management. Heart girth high and positively correlated $(\mathrm{r}=0.97 ; \mathrm{P}<0.01)$ to live body weight for all dentition groups. Hence, heart girth measurements are useful to predict live body weight in the four age groups of the Maefur indigenous goat. Most of the linear body measurements significantly $(\mathrm{P}<0.05)$ and positively correlated to live body weight. All the body measurements, except shoulder width, tail length, horn length, ear length and width, head width and head length in young (age group 04-12 months and 13-18 months) have high correlation to body weight. The correlation coefficient between live body weight and these measurements were $\mathrm{r}=0.97 ; \mathrm{P}<0.01, \mathrm{r}=0.90 ; \mathrm{P}<0.01$ and $0.88 ; \mathrm{P}<0.01$, respectively. For both sex and age groups the most important linear body measurements were heart girth, height at wither and body length. Therefore, these body traits have a potential to be used as selection criteria for Maefur goat breed. The multiple prediction equation for live body weight using these measurements was $\mathrm{LBW}(\mathrm{Y})=(0.74 \mathrm{HG}+0.16 \mathrm{BL}+0.17 \mathrm{HW})-42.77$. This model enhanced the variation of live body weight explained (95\%) by the $\mathrm{R}^{2}$. However, under pastoral and agro pastoral production system handling the indigenous goats is difficult. Heart girth, body length, and height at wither strongly and positively correlated to live body weight. These major LBM are used as selection criteria for predicting live body weight. Probably a multiple regression with the addition of other measurements to heart girth would result in significant improvements in accuracy of prediction. However, under field conditions, live weight estimation using chest girth alone would be preferable because of difficulty of the proper animal restraint during measurement. In general body weight and linear measurements are important traits in community based breed improvement. Body measurements provide quantitative measure of body size and shape that are desirable, as they will enable phenotype parameters for these traits to be estimated and permit inclusion in breeding programs.

\section{Acknowledgements}

Above all, I would like to thank the immense God for blessing invaluable gifts of health, strength, believes, love, hope, patience and protection to me and my families throughout my study. Had not been the will of God, nothing would have been possible and God give me patience and power throughout the study period. I must also give my special thanks to Dr. Eyasu Abreha, director of Tigray Agricultural Research Institute (TARI) for giving me the chance to upgrade my educational background. I am again thankful to Mekelle Agricultural Research Center for the financial support required for my study. Special thanks also go to my advisor Dr. Rohatash Kumar Bhardwaj and my co-advisor Dr. Shishir Kumar Gangwar for their earnest and constructive comments for my thesis paper. They have worked hard to keep me on the right track to prepare all the required materials for my study. My earnest gratitude and thanks also goes to Dr.Yayneshet Tesfay and Dr. Emrue who taught me research and statistical method MSc courses, respectively. In this regard, I have a full feeling of gratitude to Ato Kinfe Mezgebe, coordinator of Mekelle Agricultural Research Center (MARC) in timely adjusting my financial requests. My deepest thanks also goes to Abreham Haftue (Mekelle Agricultural Research Center) and Tikabo G/mariam (Mekelle University) for their comments in my research work. Finally, I would like to express my deepest gratitude and heartfelt thanks for the experts of livestock and extension in the study area (Erob) for their support for transportation.

\section{References}

1. Khan H, Muhammed F, Ahmed R, Rahimullah G, Zubair M (2006) Relationship of body weight with linear Body Measurement in Goat. Journal of Agricultural and Biological Science.

2. Hassan H, Ciroma A (1990) Body weight measurements relationship in Nigerian Red Sokoto goats. Department of Animal Science, Usmanur Danfodijo University, Sokoto, Nigeria

3. Nsoso S, Aganga A, Moganetsi B, Tshwenyane S (2003) Body weight, body condition score, and heart girth in indigenous Tswana goats during the dry and wet seasons in southeast Botswana.

4. Thiruvenkadan AK (2005) Determination of best-fitted regression model for estimation of body weight in Kanni Adu Kids under farmer's management system. Livestock research for rural development.

5. Otoikhian A, Otoikhian C, Akporhuarho O, Oyefia V, Isidahomen C (2008) Body measurement parameters as a function of assessing body weight in goats under on-farm research environment. African Journal of General Agriculture.

6. Taye M, Abebe G, Gizaw S, Lemma S, Mekoya A (2010) Traditiona management systems and linear body measurements of Washera sheep in the western highlands of the Amhara National Regional State.

7. FAO (Food and Agriculture Organization of the United Nations) (2011). Draft guidance on phenotypic characterization of animal genetic resource. Commission on genetic resources for food and agriculture. Thirteenth Regular Session. Rome.

8. Alemayehu T, Tikabo G, Gangwar SK (2012) Application of linear body measurement for predicting body weight of Abergelle Goat breed in Tigray region Northern Ethiopia. Global Journal of Bioscience and Biotechnology 1: 314-319.

9. Tesfay B, Mulugeta G, Tadesse A (2011) Description of cactus pear (opuntia ficus-indica (I.) mill.) Cultivars from Tigray, northern Ethiopia. Tigray Agricultural Research Institute, Mekelle, Tigray, Ethiopia.

10. Fajemilehin OKS, Salako AE (2008) Body measurement characteristics of the West African Dwarf (WAD) Goat in deciduous forest zone of Southwestern Nigeria. African Journal of Biotechnology 7: 2521-2526."

11. Hassen H, Michael B, Barbara R, Markos T (2012) Phenotypic characterization of Ethiopian indigenous goat populations. International Center for Agricultural Research in the Dry Areas (ICARDA), Syria. African Journal of Biotechnology.

12. Sebsibe A (2006) Meat quality of selected Ethiopian goat genotypes under varying nutritional conditions. Ph.D. Thesis. University of Pretoria, South Africa

13. Diao X (2010) Economic Importance of Agriculture for Sustainable Development and Poverty Reduction: The Case Study of Ethiopia. Global Forum on Agriculture 29-30 November 2010 Policies for agricultural development, Poverty Reduction and Food Security, OECD Headquarters Paris.

14. FAO (Food and Agricultural Organization) (2012) Phenotypic characterization of animal genetic resources. Animal Production and Health Guidelines.

15. Kiwuwa G H (1992) Breeding strategies for small ruminant productivity in Africa. In: Rey B, Lebbie SHB, Reynolds L (eds.). Small ruminant research, and development in Africa, Proceedings of the First Biennial Conference of the African Small Ruminant Research Network, Nairobi, Kenya.

16. Pesmen G, Yardimci M (2008) Estimating the live weight using somebody measurements in Saanen goats. Afyon Kocatepe University.

17. Solomon G (2009) Goat breeds of Ethiopia: Technical Bulleting No.27. In Kassahun AY, Gipson TA, Merkel RC (eds.) A guide for identification and utilization. Sheep and Goat Productivity Improvement Program (ESGPIP).

18. Riva J, Rizzi R, Marelli S, Cavalchini G (2002) Body Measurements in Bergamasca Sheep. Small Ruminant Research 221-227.

19. Semakula J, Mutetikka D, Kugonza DR, Mpairwe D (2010) Variability in Body Morphometric Measurements and their Application in Predicting Live Body Weight of Mubende and Small East African Goat Breeds in Uganda. East Journal of Scientific Research 5: 98-105. 